\title{
The Study of Temple Tourism Brand Marketing-Taking Guangxiao Temple as an Example
}

\author{
Mingzhu Liang, Mingsen Wang, Songjun Xu \\ Department of Tourism Management, Management School, Jinan University, Guangzhou, China \\ Email: zibuyan55@126.com
}

Received 4 July 2016; accepted 7 August 2016; published 10 August 2016

Copyright (C) 2016 by authors and Scientific Research Publishing Inc.

This work is licensed under the Creative Commons Attribution International License (CC BY). http://creativecommons.org/licenses/by/4.0/

(c) (i) Open Access

\begin{abstract}
Nowadays, religious tourism draws attention in the research field of tourism, especially the once sluggish temple. However, due to the remote geographical location, religious tourism resources have not been effectively utilized. To solve this problem, brand marketing needs to be emphasized, which could improve the scenic visibility and reputation of religious tourism. This paper uses the Guangxiao Temple as a case to analyze its brand marketing situation. We try to propose solutions through such examination.
\end{abstract}

Keywords

Religious, Guangxiao Temple, Temple Tourism, Brand Marketing

\section{Introduction}

China is a multi-religious country, which owns indigenous and endogenous religions, such as Taoism Buddhism, Islam and Christianity. There are many religious sites in China. According to statistics, the places of interest associated with religious are more than 3000. Rich religious culture resources attract followers from home and abroad, experts, scholars and ordinary tourists, which provide a solid foundation for the development of religious tourism (Su Yongjun, 2010).

Recently, with the accelerating development of China's tourism, religious tourism draws more and more attention and recognition. Some cold and cheerless religious sites begin to attract lots of tourists. In that case, religious activities sites gradually become a tourist hot spot. However, many religious resources have not yet transformed into good tourism products. Therefore, they don't receive proper social and economic benefit. Brand is essential to organization. It not only is the combination of the names or logos of enterprises' products and services, but also presents nurtured core features and competence of enterprise (Fei Zhenjia, 2001). To make the 
scenic spot develop, brand marketing is the key. Tourism product is a special product that can bring tourists spiritual satisfaction. Furthermore, tourism products also have brand. Tourism culture is the soul of tourism product brand. As a special cultural tourism product, religious resource should pay more attention to brand marketing management.

\section{Tourism Brand Marketing Overview}

Brand is the sum of consumers' overall cognition of products. In consumer's point of view, brand can be divided into two levels: one is the entity level, such as quality, features, price and appearance, and the second is the spirit level of the brand, which contains the value, personality, reputation, image and fashion, etc. Philip Kotler propses that the spirit level is more important (Zhou Qiong, 2004). In the modern marketing concept, brand is the core and soul of marketing, which attracts consumers to buy. Brand should fully transfer the unique image and attractive tourism products to consumers. Behind every brand, it has a kind of products and services, which supports the image and philosophy of brand. However, brand also need to go beyond the product or service.

Marketing is the integration of comprehensive strength of an enterprise, and it penetrates into the market positioning, product design, distribution channels and so on. The brand play a positive role in the process of the series. Brand marketing is that the enterprise links the brand's physical level and spiritual level through a series of marketing activities, and cultivates brand differences, builds brand personality, gets consumers cognition, ultimately improves the visibility and reputation of the brand.

Tourism brand refers to a benefit commitment that can bring tourists a unique spirit enjoying, it is built on the uniqueness of tourism resources or tourism region, and it is associated with a particular tourism product or tourism products group, at the same time it must show the source of that commitment and standard. A complete tourism brand should contain six meanings: 1) Property. It includes the beautiful natural scenery, profound culture, quality service, reliable continued commitment, good reputation, the concern for people body and mind, joy and enjoyment, unique experience, the attention to environmental protection, etc. Tourism brand should give the tourists a specific properties, including the unique experience of national culture and foreign culture, etc. 2) Interests. Tourists purchase tourism products primarily to the pursuit of one or some interest. 3) Value. Tourism brand should reflect the values of the tourism enterprises, including to provide a high level of service, reliable commitment, human care, etc. 4) Culture. As tourism itself is a kind of cultural phenomenon, tourism brand should highlight the cultural connotation and reflect cultural characteristics. 5) Personality. Through brand positioning, highlighting and promoting attractions geographical, historical and cultural personality. 6) Tourists. Publicity of tourism brand is to attract relevant travel enthusiasts and expand customer market (Yao Zuowei, 2001).

Tourism brand marketing can achieve the following effects: (1) Attract tourists. Due to pursuing for high level of physical and mental travel enjoy and expectations of tourism product value-added consumption, the requirements and appeal of tourists for tourism brand grow louder. (2) Enhance competitiveness. Tourism brand marketing can improve the visibility and reputation, increase customers and operating income, so as to enhance competitiveness. (3) Dig up the potential of sustainable development. Tourism brand marketing can improve the loyalty of tourists, so as to develop potential tourists (Tan Xiaojun \& Huang Xun, 2007).

\section{Introduction to Guangzhou Guangxiao Temple}

Guangxiao Temple is located in Guangxiao road, Guangzhou Guangxiao Temple is the most ancient, the largest buddhist temple in Guangdong. In March 1961 the State Council confirmed it as a national key cultural relics protection unit, managed by religious authorities (360 Good Search Wikipedia, 2013). Guangxiao Temple is one of the birthplaces of China and India buddhist cultural exchange, and it has an important status in the history of China Buddhism. It's building structure is rigorous and spectacular, in particular, it owns many historic relics, which has an important value to the study of the history of Buddhism, Guangdong history.

However, in Guangxiao Temple, I find that tourists basically are devout pilgrims and occasionally a small group of foreign visitors, and they just go around a circle without stop, therefore there is not a contribution to the tourism economy.

\section{The Present Situation of Temple Tourism Brand Development}

China's buddhist resources are rich and owns numerous temples, but in addition to some very famous temples, 
most temples’ religious tourism brand development faces some common problems, of course including Guangxiao Temple.

\subsection{Without Scientific Brand Strategy Planning}

Many temple scenic spots lack advanced, scientific evaluation system and accurate positioning to Buddhist cultural resources, on the whole, they are in a relatively isolated blind development status. On the one hand, they lack distinctive tourism products, which makes it difficult to form a tourism brand. On the other hand, these temples do not form scale operation, and it is difficult to show the Buddhist cultural characteristics, which restricts the overall development. Guangzhou Guangxiao Temple, for example, covers an area of more than 30000 square meters, the overall size is small, which is out of step with the value of the brand.

\subsection{Being Lack of Publicity}

Due to lacking market value and competitive consciousness, temples have not form the concept of self promotion, which makes many religious tourism resources unknown for a long time in addition to the minority famous religious tourism some scenic spots. For Guangxiao Temple, it hasn’t professional brand planning personnel, which makes external publicity and brand marketing not outstanding. At the same time, the quality of the scenic spot guide is uneven, and they havn't enough understanding on the philosophy of Buddhism and culture, leading to interpretations of the temple are just introduction to the history of cultural relics and sites and allusions, without further expounding the connotation and profound wisdom of Buddhism.

\subsection{Single Products and Services}

Tourism development of most temple scenic spots is just stay in the most traditional sightseeing and pilgrimage, there is very little projects that tourists can take part in, which makes tourists not really integrate into the religious culture, and therefore tourists cannot fully feel the sacred Buddhist culture. And, the service quality of many tourism enterprises is poor, these enterprises put tourism as a one-time deal, have no desire for repeat business, and lack humanized service, even cheat on tourists, which seriously influence tourism enterprises' image and development potential (Zhang Meng, 2011). The development of religious tourism commodity is very lacking, and each temple' tourism commodities are mostly stereotyped, poor quality which greatly weakens the tourists' desire to buy. And a large number of small commodities of Buddhism are sold in the small booths outside the temple, these booths lacking unified management, and they are highly incompatible with Buddhism scenic spots' solemn atmosphere.

\subsection{The Depth of Product Is Not Enough}

Religious tourism development must strive to build a strong religious atmosphere for tourists, but that is not the case. Outside the temples, it is filled with strong business atmosphere. It mainly displays in that some operators regardless of the scenic spot's management rules, utilize the tourists' religious pilgrimage mental to encourage them to buy a wide variety of goods, even fraud. For example, tour guides and business owners cooperate with each other to encourage visitors to burn incense, cheat on them, which both damages tourists' interest and besmirch the name of religion, however the functions of religion, such as enlightening wisdom, arousing the moral and psychological balance, restoring the value of life, relaxing etc. are seldom developed (Chang Jingliang, 2013).

\subsection{Single Tourist Type}

In temples the most common tourists are the devoutly Buddhist believers, who are often referred to as pilgrims. Ordinary tourists are very rare, and only part of the tourists can be affected by the sacred atmosphere to burn incense, while most of the tourists often take photos and talk loudly, which influences the sacred image of temples. However temples do not make proper counseling so that ordinary tourists don't gain their proper tourism value and even destroy the mood of pious pilgrims, undermining the image of the temple.

\section{Temple Tourism Brand Marketing Countermeasures}

Compared with general tourism products, religious tourism itself has particularity and multiple value to society. 
So it is important to make multi-dimensional value analysis to religious tourism, which will help the industry awareness of the value of religious tourism, especially the social value of religious tourism, which is rarely involved in other tourism products. For the above problems and Guangzhou Guangxiao, the author proposes some corresponding marketing strategies to make the temple tour get better development.

\subsection{Improve the Organizational Structure and Management System of Temples}

Organization is the skeleton of the enterprise, is the hardware to support enterprise. Complete and effective organization not only provides the operation of resources or elements with the most appropriate space, but also can partially compensate or alleviate the defects of resources, elements, etc. As Guangxiao Temple is a Buddhism temple, therefore it can't set up departments depend on demands as enterprises do. Guangxiao Temple should adjust its organization structure according to the actual situation so as to the structure is in favor of modern brand operation, then it can make a scientific brand strategy planning to lay a good foundation for the innovation and communication of Guangxiao Temple.

\subsection{Use Network Markerting to Spread}

For the problem that the awareness is not high, Guangxiao Temple should take active measures to make the world have a more comprehensive and accurate understanding to temple culture. Therefore it is a good choice to use high-tech boldly, such as web marketing, viral marketing, microblog and WeChat marketing, to promote the temple, so as to let more people know the temple.

\subsection{Integrate Various Resources and Strengthen the Participation of Religious Activity}

Any individual does not exist independently, temple is the same. Operators can actively develop the surrounding resources to enrich tourism projects. For Guangxiao Temple, it is located in Guangxiao Road. As an ancient street, Guangxiao Road has many old restaurants, so Guangxiao Temple can borrow from these honored for integrated marketing, but also enrich the tourism service content. At the same time, there are many Buddhist festivals. Developing these festivals can increase travel experience projects and strengthen religious tourism participation, so as to satisfy the intense curiosity and novelty to religious of tourists.

\subsection{Dig the Connotation of Buddhism Tourism}

Any tourism brand has a certain life cycle, and the cultural connotation is the key to extend the life cycle of tourism brand, it is mainly reflection of personalized tourism brand marketing (Fang Xiaoying, 2010). When the temple develops Buddhist tourism commodities, it can develop the Buddhist temple architecture, calligraphy of Buddhism, Buddha, murals as crafts and souvenirs. Developing and designing these Buddhist tourism commodities not only can change the low-quality and featureless status of tourism commodity to improve the culture grade of tourism commodities, but also can improve the Buddhist tourism competitiveness of Guangxiao Temple and increase its tourism income (Wu Qiang, 2008).

\subsection{Clear Positioning and Make Market Segment}

Different tourists have different purposes, and their needs are different too. Since the temple has become a part of tourism, it should be integrated into tourism, not only preserving its sacred side, but also integrating into the diversified market, making some changes, meeting the ordinary tourists so as to let ordinary people also can get purification of the mind. There is a contradiction between tourists and pilgrims in the temple for the space and the atmosphere, therefore, the temple should posts notices about the procedure of burning incense, Buddhist sense and visit considerations at the gate of the temple to correctly guide the behavior of different types of tourists. In addition, in the temple there should be clearly schematic diagram to indicate the directions of different places. At the same time, the temple should manage to separate tourists and pilgrims activity areas through the adjustment of facilities layout, for example, tourists like to take photos in front of the gate, so the temple can set incense burner on both sides. Subdivide these two types of tourists, take different service strategies, so as to let ordinary tourists can also participate in the worship, which means that those tourists not only achieve the purpose of tourism, but also gain some spiritual enlightenment. Of course the events of ordinary tourists should be separated with the pilgrims worship, and don't let them affect each other. 


\section{Conclusion}

As a special tourism product, temple tourism' development and marketing should not be confined in tangible resources of material level. More attention should be paid to intangible resources of spiritual level.

At present, the construction and management of temple scenic spots are still in its beginning stage. If they want to achieve long-term growth of the tourism economy, they must own a good tourism brand, and set up the health tourism image. Through the gradual exploration of brand building, the prospects of temple tourism will be better (Dai Di, 2014).

\section{References}

360 Good Search Wikipedia (2013). http://baike.haosou.com/doc/5346903-5582350.html

Chang Jingliang 昌晶亮 (2013). The Depth Development Analysis of Nanyue Religious Tourism Products 南岳宗教旅游 产品深度开发探析. Journal of Central South University of Forestry \& Technology (Social Sciences), 5, 18-21.

Dai Di 代迪 (2014). Jinzhou Tourism Brand Marketing Countermeasures 锦州旅游品牌营销对策. Co-Oerativeconomy \& Science, 23, 78-79.

Fang Xiaoying 方小英 (2010). The Research of Shaolin Temple Brand Marketing 少林寺品牌营销研究. Zhengzhou: Zhengzhou University.

Fei Zhenjia 费振家 (2001). Tourism Brand Marketing Research of Wudang Mountain 武当山旅游品牌营销研究. Journal of Shiyan Technical Institute, 1, 46-52.

Su Yongjun 苏勇军 (2011). The Construction and Development of Religious Tourism Products System—Taking Zhejiang Province as an Example 宗教旅游产品体系的构建及其开发研究——以浙江省为例. Journal of Tourism College of Zhejiang, 1, 16-21.

Tan Xiaojun, \& Huang Xun 谭小军, 黄勋 (2007). The Research of Tourism Brand Marketing 旅游品牌营销研究. Journal of Jiangxi Science \& Technology Normal University, 6, 35-37.

Wu Qiang 吴蓄 (2008). The Development Study of Ningbo Buddhist Tourism Resource 宁波佛教旅游资源开发探讨. Market Modernization, 31, 278-279.

Yao Zuowei 姚作为 (2001). The Exploration of Our Country Tourism Brand Process 我国旅游业品牌化进程初探. Economic Survey, 5, 94-96.

Zhang Meng 张萌 (2011). The Implementation of the White Horse Temple Religious Tourism Brand Strategy 白马寺宗教 旅游品牌战略的实施. China Business \& Trade, 11, 187-188.

Zhou Qiong 周琼 (2004). To Discuss the Marketing Innovation under the Experience Economy 论体验经济下的营销创 新. Special Zone Economy, 12, 227-228.

\section{Submit or recommend next manuscript to SCIRP and we will provide best service for you:}

Accepting pre-submission inquiries through Email, Facebook, LinkedIn, Twitter, etc.

A wide selection of journals (inclusive of 9 subjects, more than 200 journals)

Providing 24-hour high-quality service

User-friendly online submission system

Fair and swift peer-review system

Efficient typesetting and proofreading procedure

Display of the result of downloads and visits, as well as the number of cited articles

Maximum dissemination of your research work

Submit your manuscript at: http://papersubmission.scirp.org/ 